\title{
Influence of the hydrothermal alteration rocks on the stability of an open pit mine of the south of Peru: a case study
}

\author{
S Castro Anddes, Peru \\ C Huaman Anddes, Peru
}

\begin{abstract}
Hydrothermal solutions considerably modify the physical and mechanical properties of rocks, and consequently have an impact on the pit slope stability; however, this effect is sometimes not sufficiently considered in an open pit slope design and the geotechnical model is only based on lithology. This could cause during mining, variable and poor rock mass qualities to be observed with respect to those assumed in the design. This generates the need for redesign of the pit slopes based on additional geotechnical investigations such as surface mapping on the existing benches, to develop or update the geotechnical model based on hydrothermal alteration and then carry out the slope stability analysis (Factor of Safety and displacements). The case study presented in this paper shows that the zonation in terms of hydrothermal alteration types is required when there is a strong influence of this phenomenon, but also needs to be accompanied by a zonation based on variability of rock strength in each alteration type, since the effect can be very intense up to transform the rock in residual soil.
\end{abstract}

Keywords: hydrothermal alteration, open pit, weak rocks, residual soils

\section{Introduction}

This case study is referred to as an open pit mine located in the South of Peru. It consists of a gold deposit that evidences the effects of hydrothermal alteration on the intact rock and rock mass, due to chemical changes, resulting on degradation of geotechnical strength properties. Most of rocks of the final open pit walls have an intact rock strength lower than R2 (weak rocks) and poor or low quality rock mass (Rock Mass Rating $\left.\left(\mathrm{RMR}_{89}\right)<41\right)$ ). Among the main hydrothermal alterations there are: Vuggy silica, advanced argillic and intermediate argillic. These alterations associated with hydrothermal orebodies change considerably the strength and quality of rock host.

In this open pit, rock mass weathering grades are from III to VI (moderately weathered to residual soil according to Deere \& Patton (1971)), and the $90 \%$ of the rock mass rating (RMR 89 ) is under 61 (residual soil to fair rock). It's principally due to the presence of weak rocks categorised as hydrothermally altered rocks which is one of the five categories illustrated in Figure 1 (obtained from Martin \& Stacey 2013).

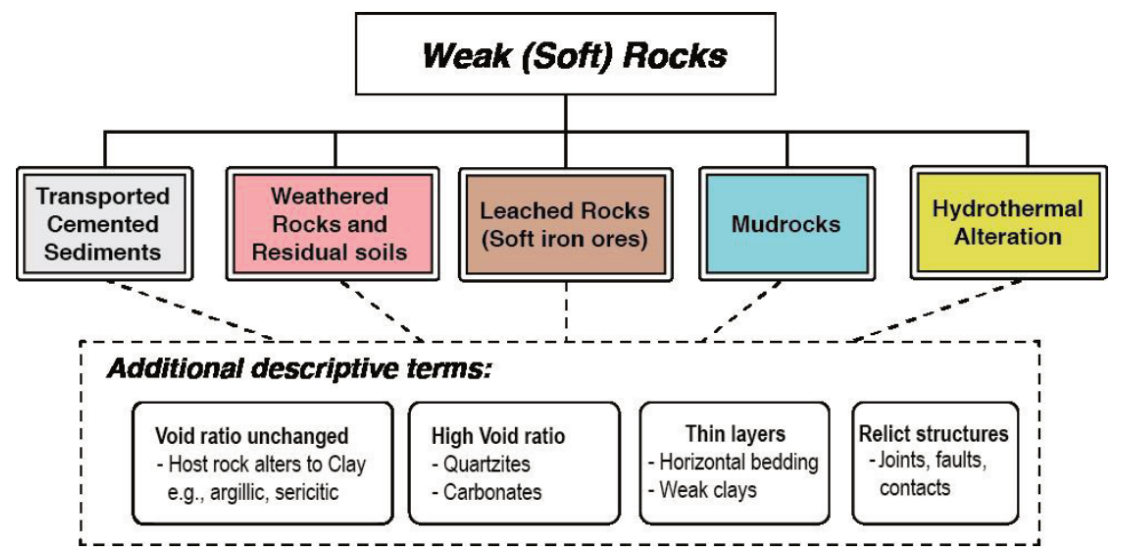

Figure 1 The five geology categories classed as weak rocks (Martin \& Stacey 2013) 
However, in the early engineering studies of the project, geotechnical characterisation had been developed only based on lithology, and few boreholes and laboratory tests were used in the database for running the geotechnical model. Those limited actions generated inconsistencies between the geotechnical model and the open pit wall materials, which was evidenced during the mining operation; additionally, poorly controlled blasting and some erosion were observed on the upper slopes.

Fortunately, the groundwater level in this area (based on a mine scale hydrogeologic study) is $50 \mathrm{~m}$ under the deeper level of the final open pit bottom according to the existing design.

All the above reasons generated the need to conduct additional geotechnical investigation which included a field and laboratory campaign, data processing and interpretation, and developing of a 3D geomechanical model and the assessment of the stability of the existing open pit design.

\section{Field data collection and laboratory tests}

A field geotechnical investigation campaign was carried out between the months of December 2018 and March 2019, which consisted on the geological-geotechnical mapping and logging of the existing open pit benches, supervision of oriented core drilling and sampling of representative materials in many sectors of the open pit walls. This research complemented the data previously obtained by other consultants.

Among the main laboratory tests carried out for soils were Unified Soil Classification System (USCS), unit weight of undisturbed samples, and consolidated undrained triaxial compression. For intact rock core specimens the tests were point load strength index, unconfined compressive strength (UCS) and elastic moduli, splitting tensile strength and direct shear strength for discontinuities. All the above data allowed to obtain the physical and strength materials properties.

Figure 2 shows the particle size distribution curves of sampled soils during geological mapping and drillings. Residual soils of the main hydrothermal alterations existing on the pit benches, vuggy silica, advanced argillic and intermediate argillic are mainly classified, based on USCS, as silty sand (SM). Likewise, moraines classify as a clayey-silty gravel (GC-GM).

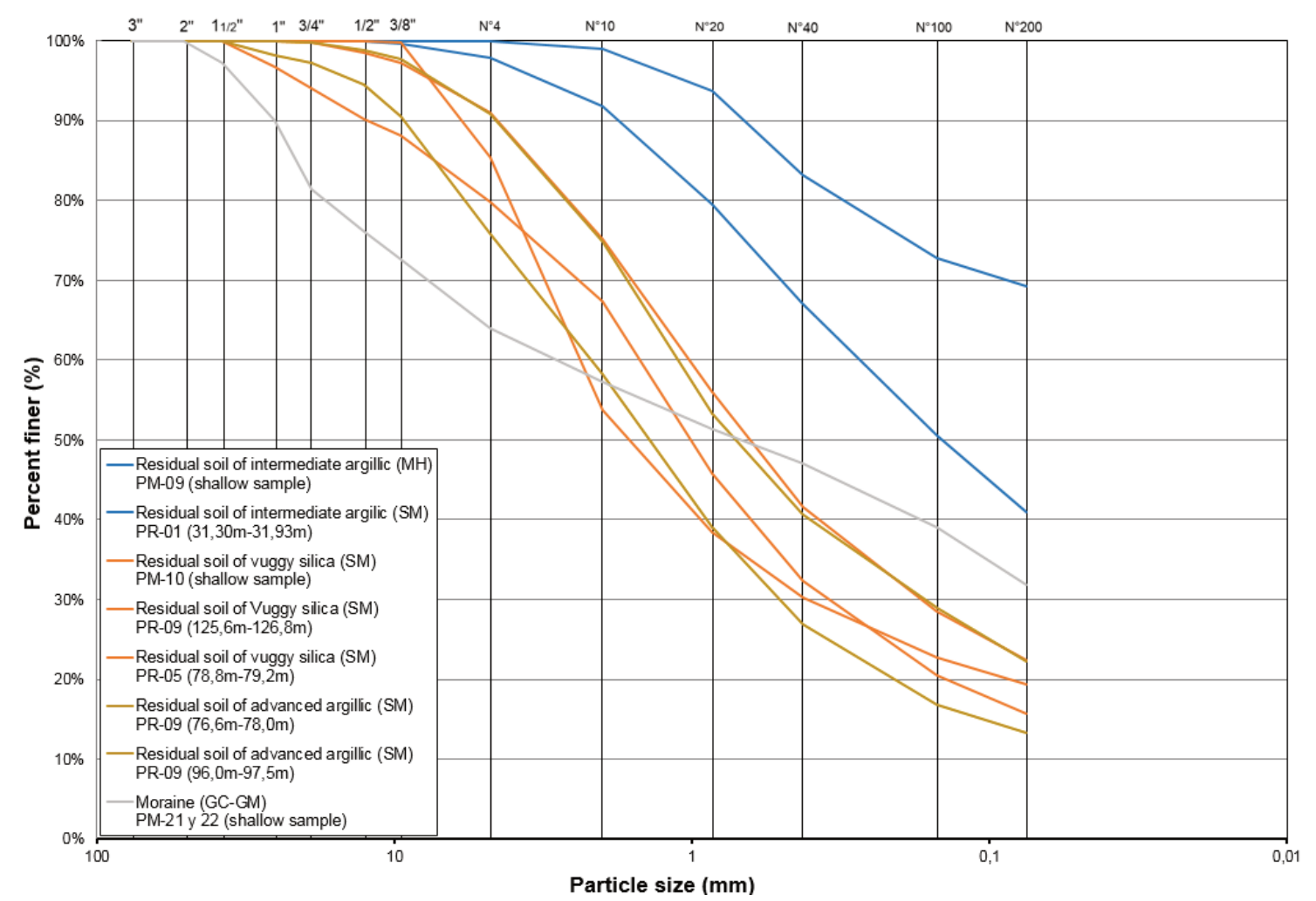

Figure 2 Particle size distribution curve of residual soils 
Figure 3 shows the fit obtained between porosity and absorption after plotting the intact rock cores tested by Anddes and the previous tests from other consultants.

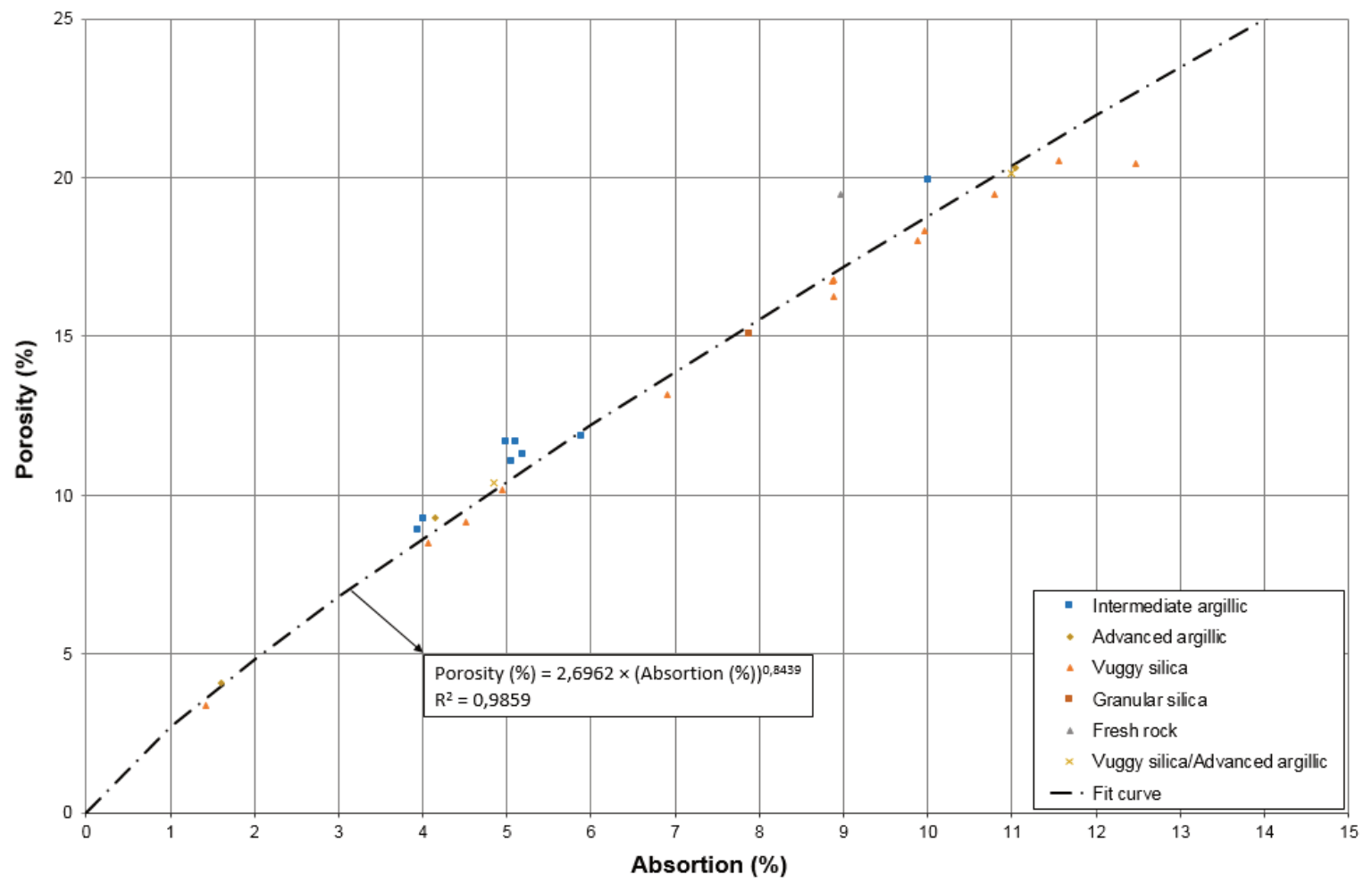

Figure 3 Porosity (\%) versus absorption (\%) fit for available laboratory tests

Figure 4 shows the lineal fit obtained between unit weight of intact rock cores tested by Anddes and the previous tests from other consultants. It should be noted that the equations presented are the ones that best fit and were performed for the types of alteration with available laboratory tests.

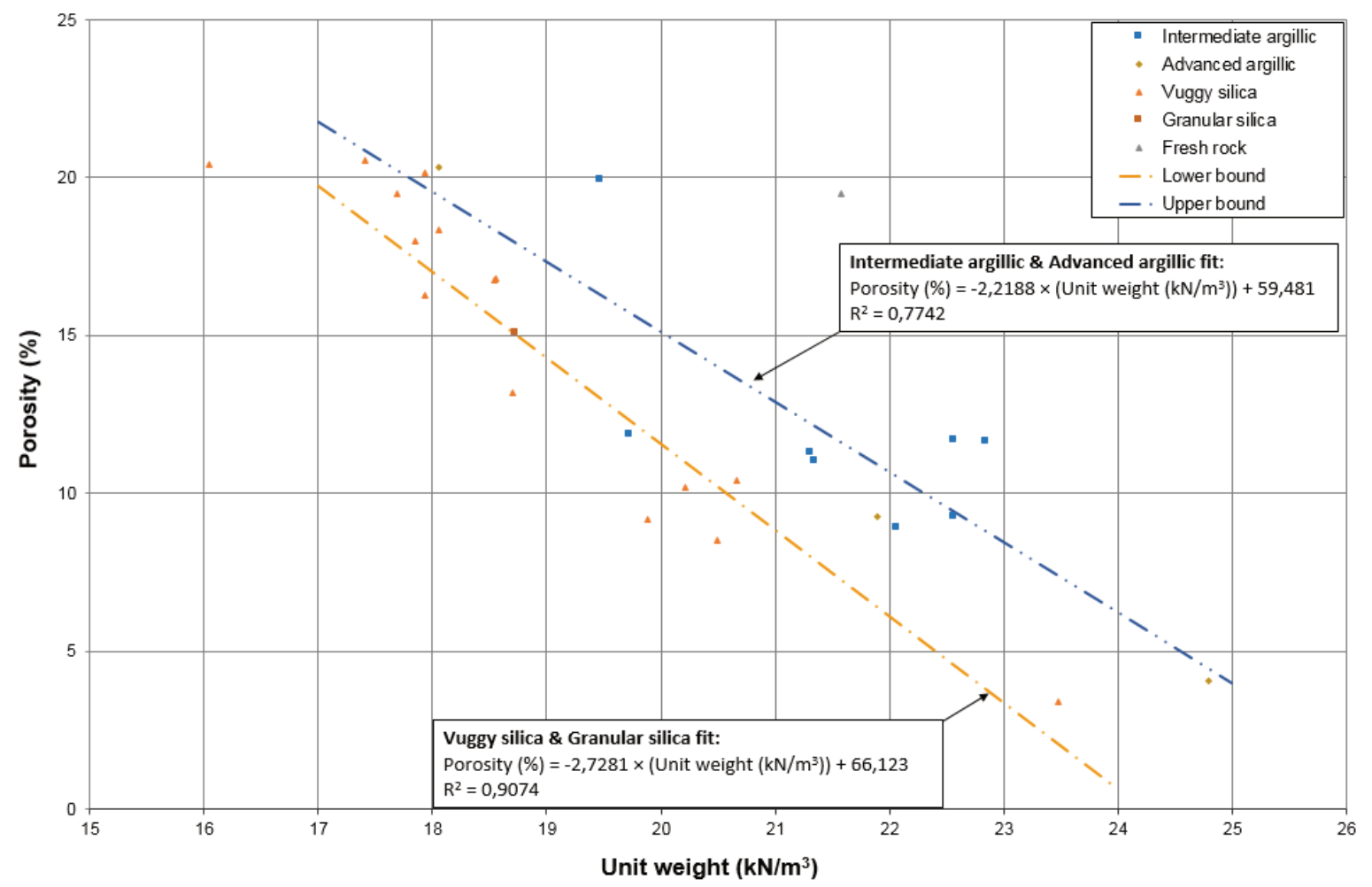

Figure 4 Porosity (\%) versus unit weight $\left(\mathrm{kN} / \mathrm{m}^{3}\right)$ fit for available laboratory tests 
Figure 5 shows the non-linear fit obtained between shear stress and normal stress after plotting the direct shear tested by the current and the previous tests from other consultants. They were obtained in case of failures through structures had to be analysed.

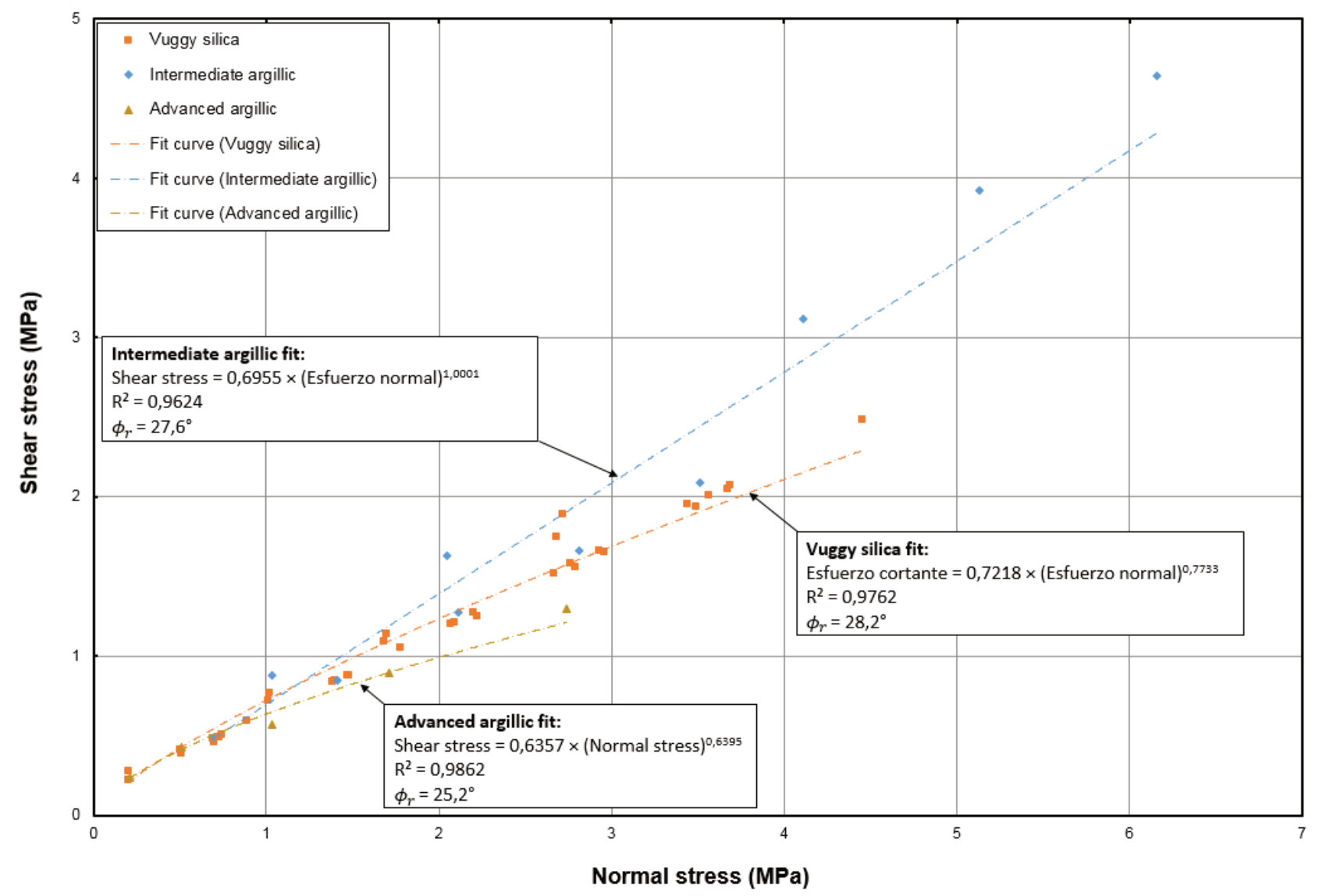

Figure 5 Shear-normal stress non-lineal functions for joints based on direct shear tests

Figure 6 shows the $\mathrm{RMR}_{89}$ values compared with two formulations to obtain the Geological Strength Index (GSI) (Hoek et al. 1995, 2013). Hoek et al. (1995) proposes to use GSI = RMR 89 - 5 considering rock masses without groundwater influence and without adjustment for discontinuity orientation, constraining their use to rock masses with $\mathrm{RMR}_{89} \geq 30$. Otherwise, Hoek et al. (2013) which proposes a quantification of the GSI table proposed by Marinos \& Hoek (2000), proposed an estimate of the GSI based on the surface condition of the discontinuities (from the joint condition rating ( $\mathrm{JCond}_{89}$ ) defined by Bieniawski (1989)) and the interlocking of the defined rock blocks for discontinuities (from the Rock Quality Designation (RQD) defined by Deere et al. (1967)) proposing to use GSI $=1.5 \mathrm{~J} \mathrm{Cond}_{89}+\mathrm{RQD} / 2$, which presents a variation of \pm 10 with respect to the GSI obtained from chart. Finally, Anddes used Hoek et al. (1995) as it presented closer values to those recorded in the outcrops mapped at benches near the drillholes, while Hoek et al. (2013) overestimated GSI' values. 


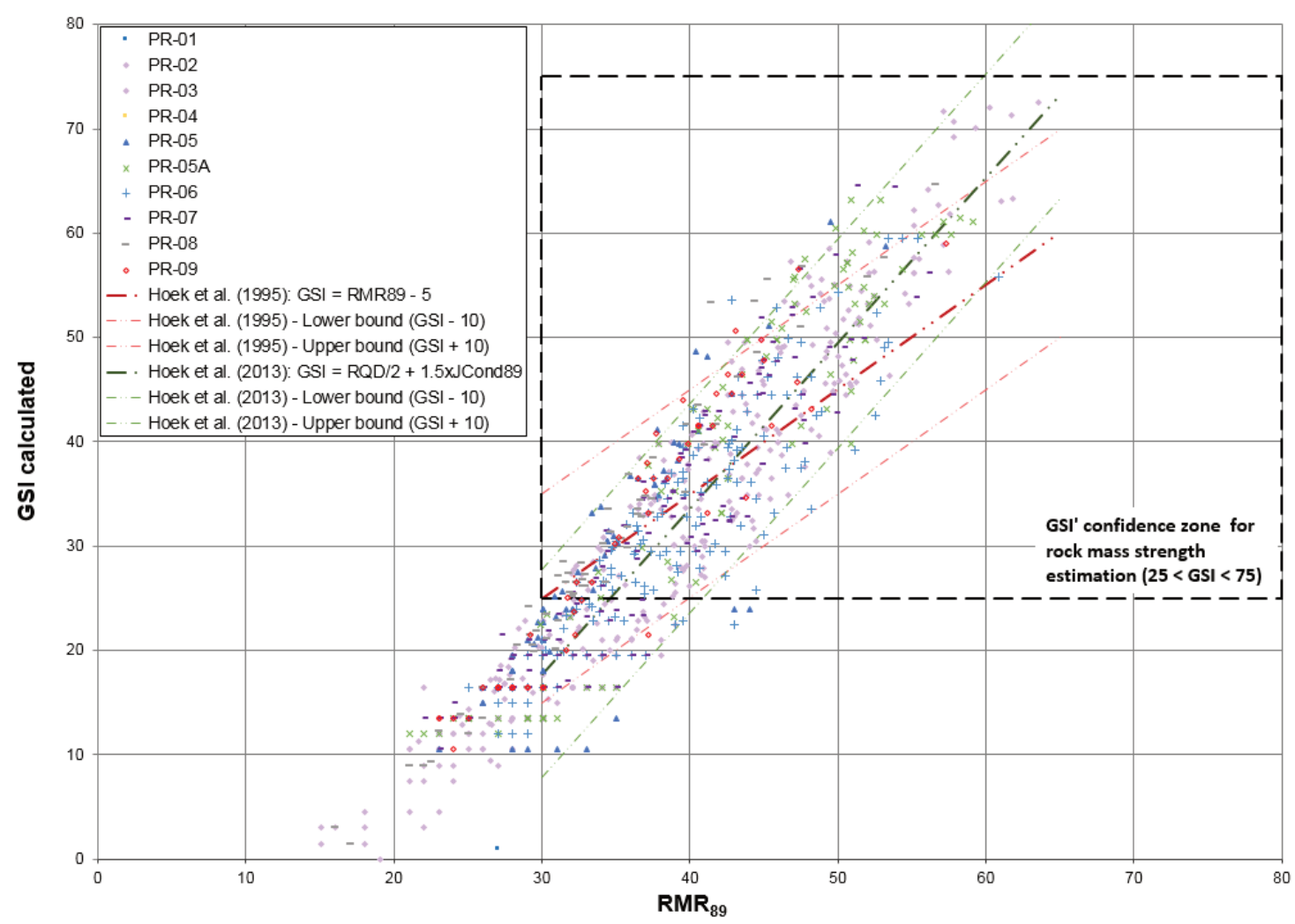

Figure $6 \quad \mathrm{RMR}_{89}$ obtained from drill logs versus Geological Strength Index (GSI) calculated using the formulation proposed by Hoek et al. (1995) and Hoek et al. (2013)

Table 1 presents geotechnical units defined in the open pit. Geotechnical unit I is for moraines, geotechnical unit II is for residual soils, geotechnical unit III is for very poor to poor rock masses and geotechnical unit IV is for fair rock masses. Geotechnical units III and IV were subdivided considering the range of RMR 89 values (as shown in Table 1). Materials were named according to the type of soil or hydrothermal alterations type.

Table 1 Geotechnical units (continued next page)

\begin{tabular}{lll}
\hline Material & Geotechnical unit & Range of RMR $_{\mathbf{8}}$ values \\
\hline Moraines & I & Moraines \\
\hline II & III & Residual soil \\
Advanced argillic & III & $17 \leq \mathrm{RMR} \leq 20$ \\
& III & $20<\mathrm{RMR} \leq 30$ \\
& IV & $30<\mathrm{RMR} \leq 40$ \\
& IV & $40<\mathrm{RMR} \leq 50$ \\
& II & $50<\mathrm{RMR} \leq 60$ \\
\hline Intermediate argillic & III & Residual soil \\
& III & $17 \leq \mathrm{RMR} \leq 20$ \\
\cline { 2 - 3 } & IV & $20<\mathrm{RMR} \leq 30$ \\
& & $30<\mathrm{RMR} \leq 40$ \\
\hline
\end{tabular}




\begin{tabular}{|c|c|c|}
\hline Material & Geotechnical unit & Range of $\mathrm{RMR}_{89}$ values \\
\hline & IV & $50<\mathrm{RMR} \leq 60$ \\
\hline \multirow{6}{*}{ Vuggy silica } & II & Residual soil \\
\hline & III & $17 \leq \mathrm{RMR} \leq 20$ \\
\hline & III & $20<\mathrm{RMR} \leq 30$ \\
\hline & III & $30<\mathrm{RMR} \leq 40$ \\
\hline & IV & $40<\mathrm{RMR} \leq 50$ \\
\hline & IV & $50<\mathrm{RMR} \leq 60$ \\
\hline \multirow{3}{*}{ Granular silica } & II & Residual soil \\
\hline & III & $17 \leq \mathrm{RMR} \leq 20$ \\
\hline & III & $20<\mathrm{RMR} \leq 30$ \\
\hline \multirow{3}{*}{ Massive silica } & II & Residual soil \\
\hline & III & $17 \leq \mathrm{RMR} \leq 20$ \\
\hline & III & $20<\mathrm{RMR} \leq 30$ \\
\hline
\end{tabular}

Figure 7 shows the materials qualities obtained using all geologic-geotechnical available data that helped to define four geotechnical units: geotechnical unit I (moraines), geotechnical unit II (residual soils), geotechnical unit III (very poor and poor rock mass) and geotechnical unit IV (fair rock mass). To define rock strength properties, geotechnical units III \& IV were subdivided according to the rock mass quality (RMR value).

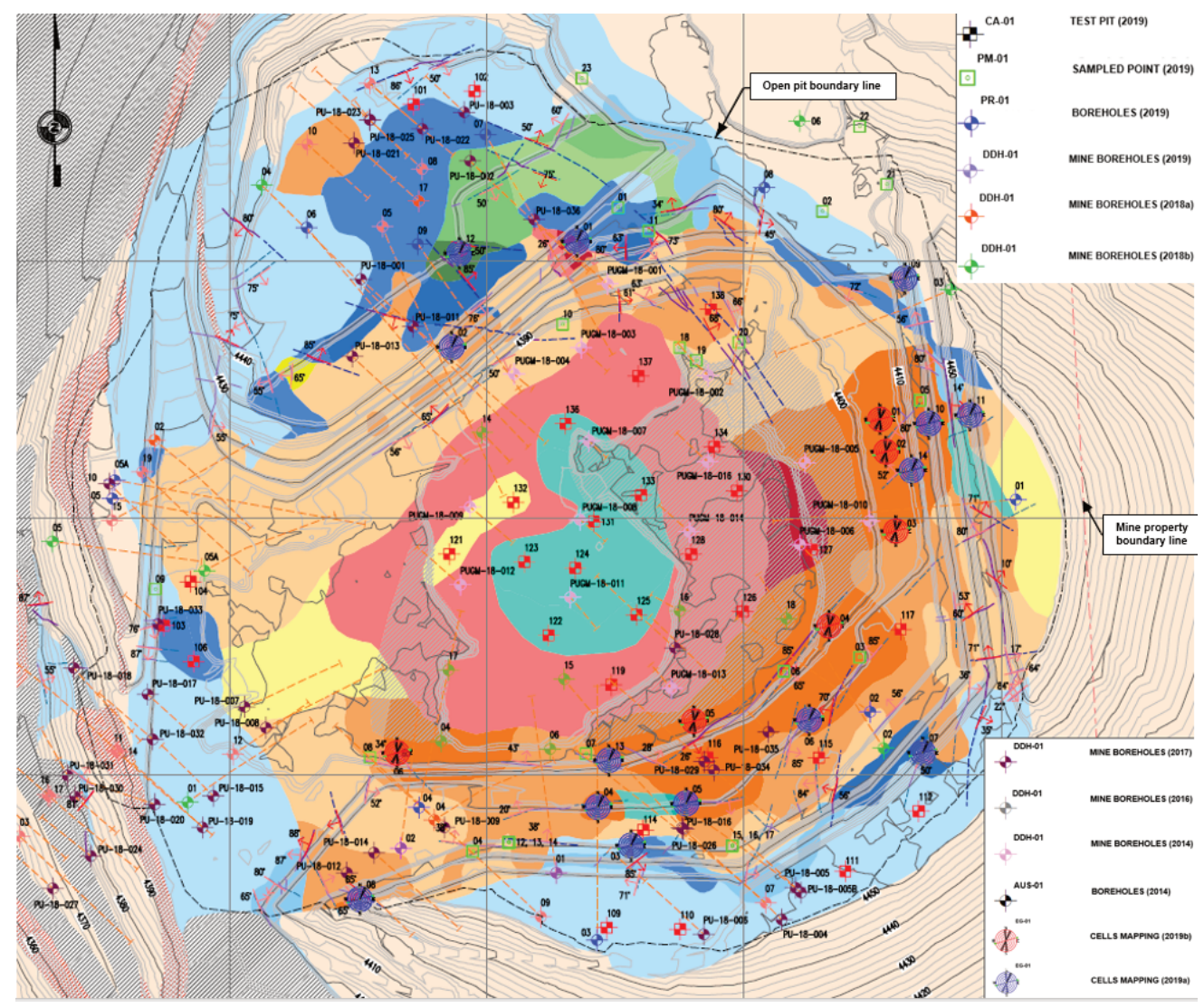

Figure 7 Current open pit geology (view colours legend for geotechnical units in Table 1) 


\section{Geomechanical model}

The tridimensional interpretative geomechanical modelling of the open pit was developed using MinePlan ${ }^{\mathrm{TM}}$ 3D (Hexagon Mining 2018). Data used consisted in existing geological, geometallurgical and geotechnical core drilling, coming from different field campaigns carried out by the mining company, Anddes and other consultants. From these drillings, those located within the limits of the open pit design were selected, and corrections were made to some of the parameter ratings (to obtain RMR ${ }_{89}$ ) assigned during the field campaigns.

Data of 100 boreholes were used (10 of them belong to Anddes geotechnical campaign). In addition, the available surface data from mapping at existing benches (converted to boreholes of short length for modelling purposes) were used to augment and improve the input data to the geomechanical model.

During the review of the available drilling cores logs and boxes, errors were found in the parameters punctuation, so it was necessary to standardise these logs as Bieniawski (1989). Some errors observed consisted on overestimate $\mathrm{RMR}_{89}$ value in very poor rocks (class $\mathrm{V}$ ), residual soils hadn't been logged correctly so they were logged using $\mathrm{RMR}_{89}$, and $\mathrm{RMR}_{89}$ assigned values for poor, fair and good rocks (classes IV, III \& II, respectively) had some errors on discontinuities rating. In summary, most of errors were observed for values of $\mathrm{RMR}_{89} \leq 20$ (very poor rocks \& residual soils).

The comparative of the total length of cores logged by Anddes versus the total drillcores available were classified by the RMR values as shown in Figure 8. It is observed that available data increased considerably, improving the geomechanical model reliability.

\section{Logged length (m) vs $\mathrm{RMR}_{89}$}

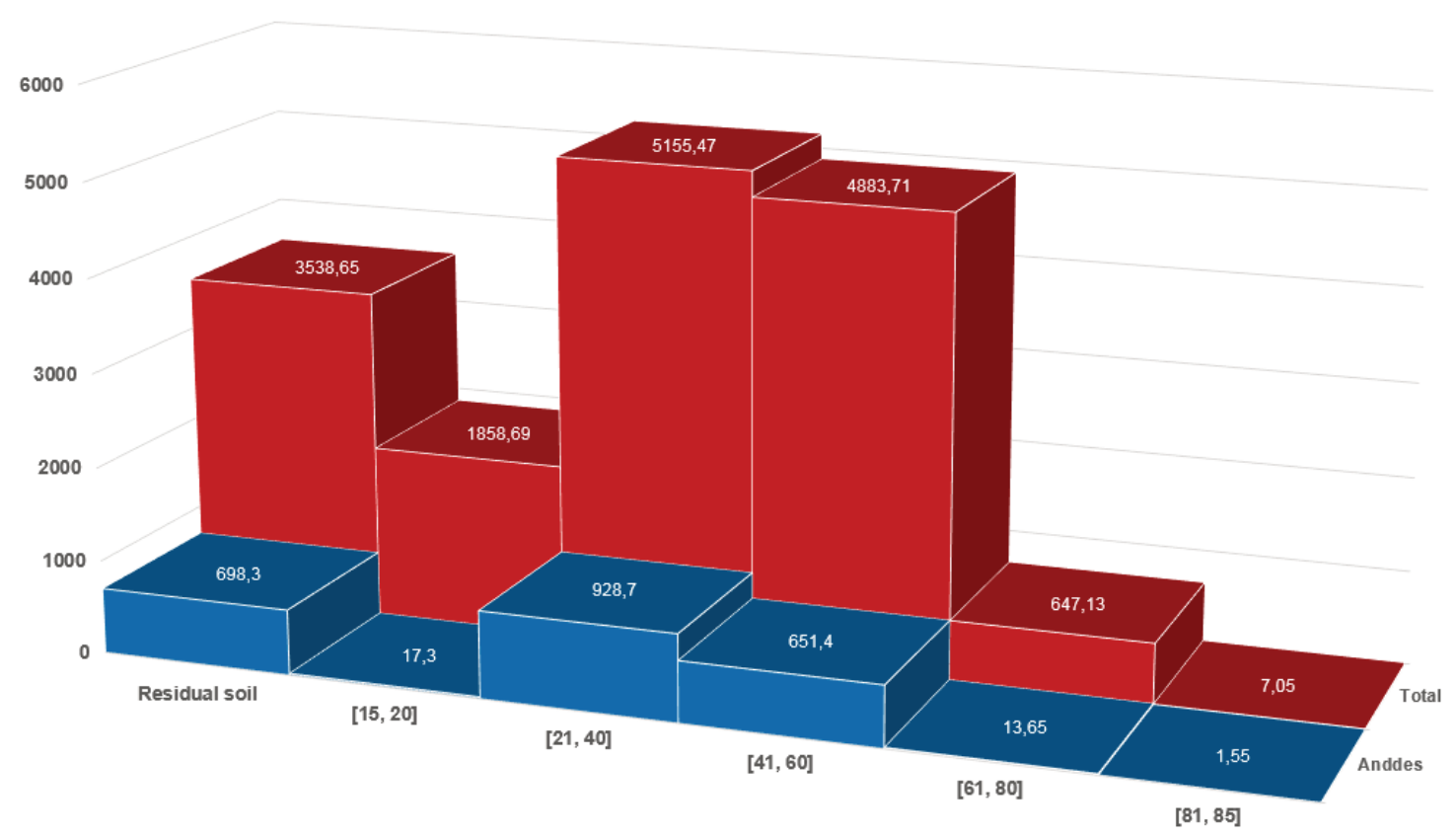

Figure 8 Comparative of total length logged for each interval of $\mathrm{RMR}_{89}$ obtained from Anddes drillcores and the total drillcores available

In Figure 9, logged cores length percentage (based on the total length shown in Figure 8) is graphed. It is observed that rock mass quality data (based on Bieniawski (1989)), available to develop the geomechanical model, is mainly concentrated in three classes: fair rock, poor rock and residual soils. 


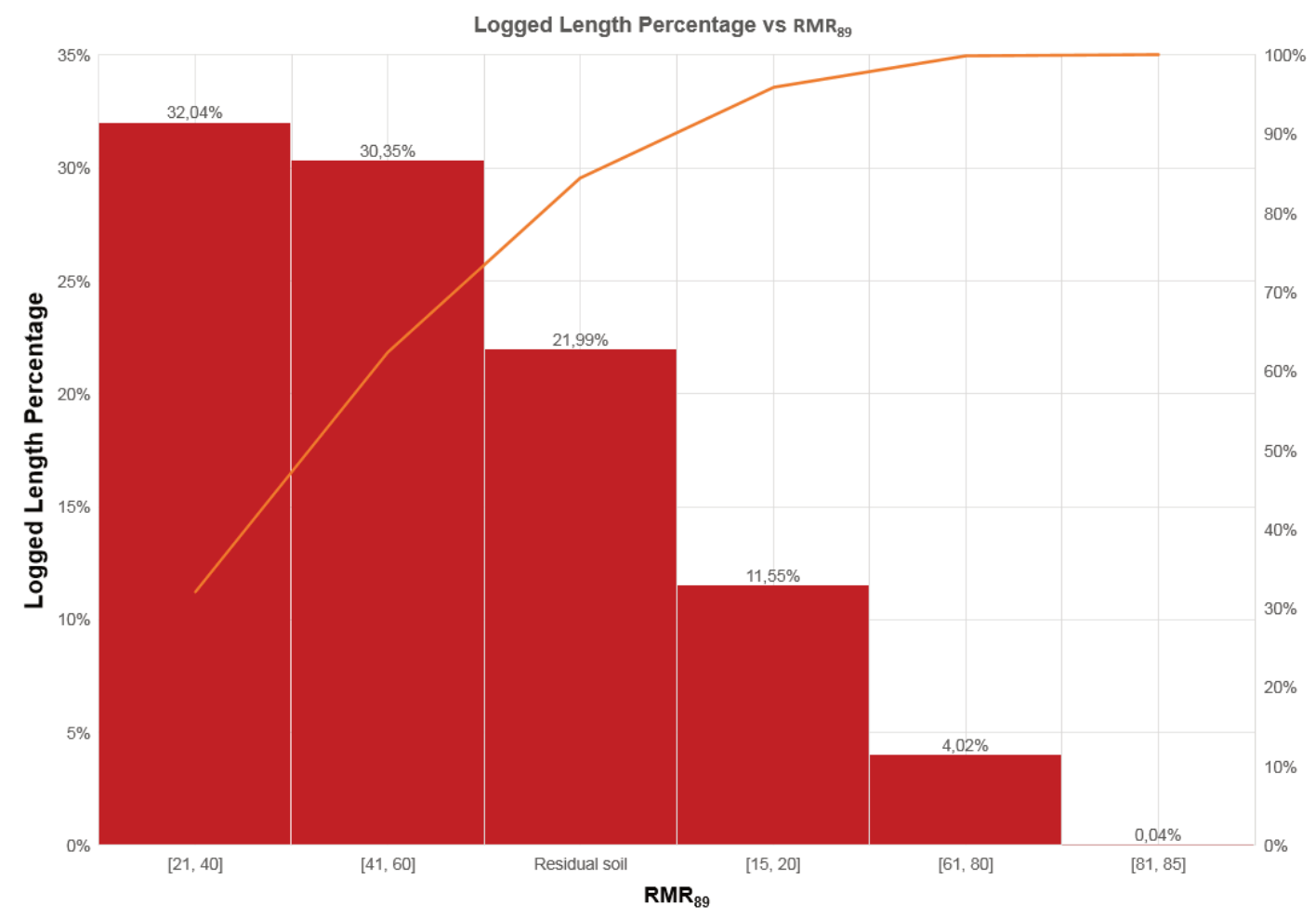

Figure 9 Logged cores length percentage (respect to total length logged) for each interval of $\mathrm{RMR}_{89}$ obtained from the total drillcores available

Table 2 shows the lengths associated with each rock mass class comparing the original data available and the corrected core logs. It was assumed that 'no data' is due to residual soils that could not be recovered in cores. It is also good to indicate that all available data was used to model the open pit area in current condition (not completely excavated).

Table 2 Comparison between original data and corrected core logs

\begin{tabular}{|c|c|c|c|c|c|}
\hline \multirow{2}{*}{ Classification } & \multirow{2}{*}{$\mathrm{RMR}_{89}$ range } & \multicolumn{2}{|c|}{ Original data } & \multicolumn{2}{|c|}{ Corrected data } \\
\hline & & Length (m) & Percentage (\%) & Length (m) & Percentage (\%) \\
\hline Residual soil & - & - & - & $2,101.45$ & 22.01 \\
\hline Very poor & $17-20$ & 3 & 0.03 & 911.15 & 9.54 \\
\hline Poor & $21-40$ & 6202.1 & 64.95 & 3882.7 & 40.66 \\
\hline Fair & $41-60$ & $2,981.75$ & 31.23 & 2447.5 & 25.63 \\
\hline Good & $61-80$ & 309.95 & 3.25 & 206.2 & 2.16 \\
\hline No data & - & 52.2 & 0.55 & - & - \\
\hline \multicolumn{2}{|c|}{ Total } & 9,549 & 100 & 9,549 & 100 \\
\hline
\end{tabular}

The block model obtained contains the following geomechanical properties: unconfined compressive strength (UCS) of intact rock, degree of fracturing (RQD) and geomechanical classification of the rock mass $\left(\mathrm{RMR}_{89}\right)$, which were subsequently used for the assessment of the open pit slope stability.

Once the geomechanical block model was prepared, the views of the $\mathrm{RMR}_{89}$ and $\mathrm{RQD}$ values projected to the final surface of the pit were obtained. These views and an example cross-section are shown in Figures 10 and 11 for RMR and RQD values, respectively. Values are related to colour shown in Table 3. 
Table 3 Colours and values used to show the qualities (expressed on $\mathrm{RMR}_{89}$ and RQD) of the geomechanical model materials

\begin{tabular}{cc}
\hline $\begin{array}{c}\text { Range of RMR } \\
\text { values }\end{array}$ & $\begin{array}{c}\text { Range of RQD } \\
(\%) \text { values }\end{array}$ \\
\hline $0^{(1)}$ & $0^{(1)}$ \\
$(0-17)^{(1)}$ & $(0-25)$ \\
$(17-20)$ & $(25-50)$ \\
$(20-30)$ & $(50-75)$ \\
$(30-40)$ & \\
$(40-50)$ & $(75-90)$ \\
$(50-60)$ & \\
$(60-85)^{(2)}$ & \\
\hline
\end{tabular}

In case a material has $\mathrm{RMR}_{89} \leq 17, \mathrm{UCS}=0$ y $\mathrm{RQD}=0$, for practical purposes it'll be considered as a residual soil. In general, maximum $\mathrm{RMR} 89$ value registered is 75; just a few values are between 76-85. RMR 89 - Rock Mass Rating; RQD - Rock Quality Designation.

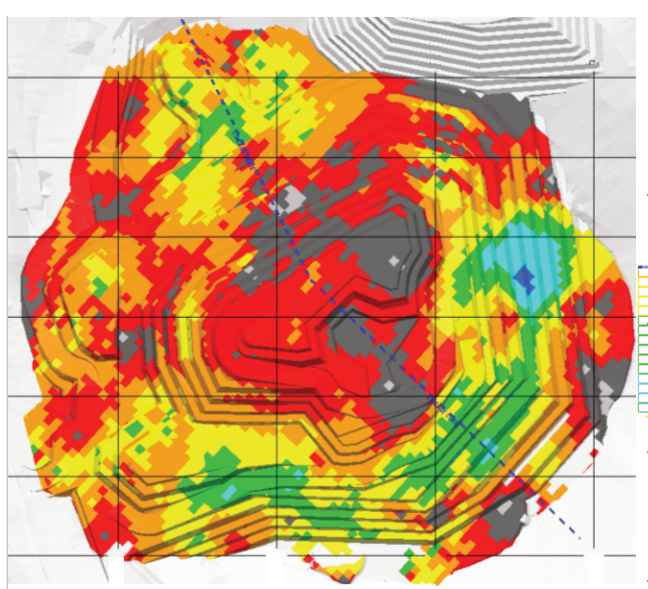

(a)

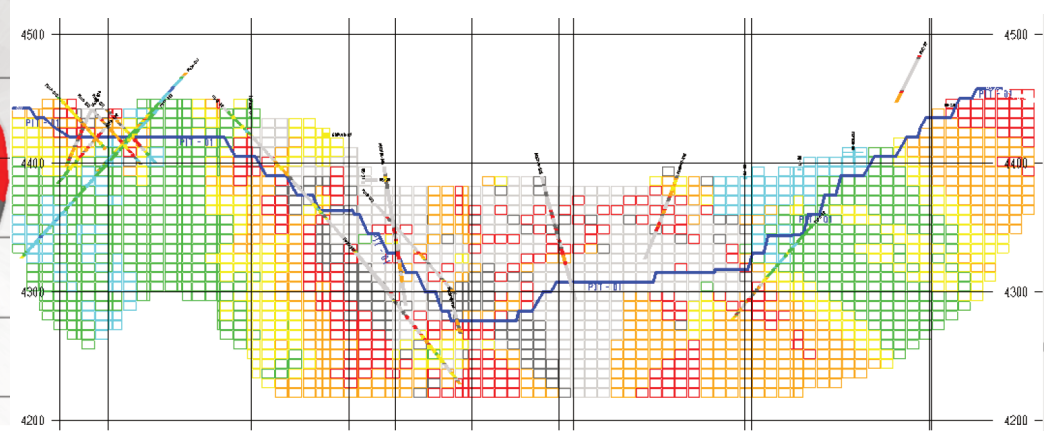

(b)

Figure 10 (a) Plan view of $\mathrm{RMR}_{89}$ values (projected to the final pit) obtained from the geomechanical model; and (b) Cross-section view of the line shown in Figure 10a

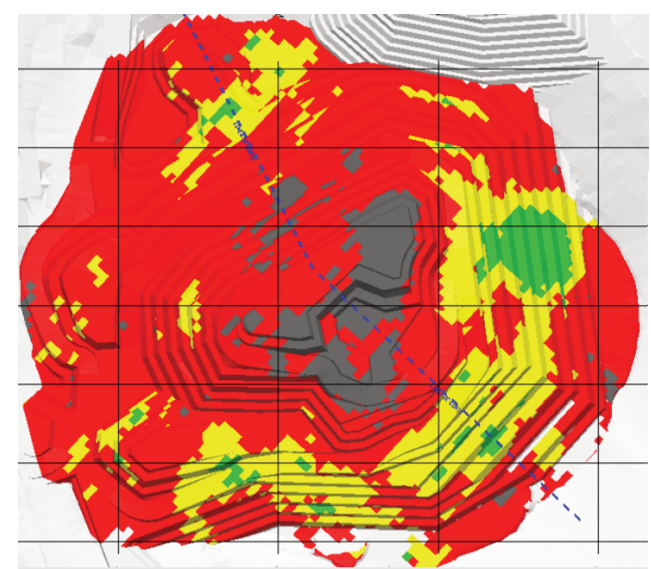

(a)

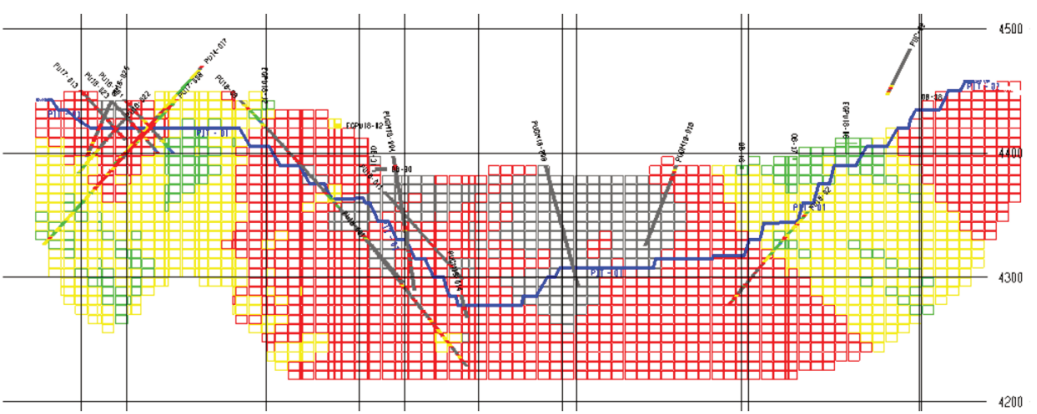

(b)

Figure 11 (a) Plan view of RQD values (projected to the final pit) obtained by the geomechanical model developed; and (b) Profile view of the section line shown in Figure 11a 
Figure 12 shows the material qualities obtained intersecting the geomechanical model and the current open pit design. It shows four geotechnical units: geotechnical unit I (moraines), geotechnical unit II (residual soils), geotechnical unit III (very poor and poor rock mass) and geotechnical unit IV (fair rock mass).

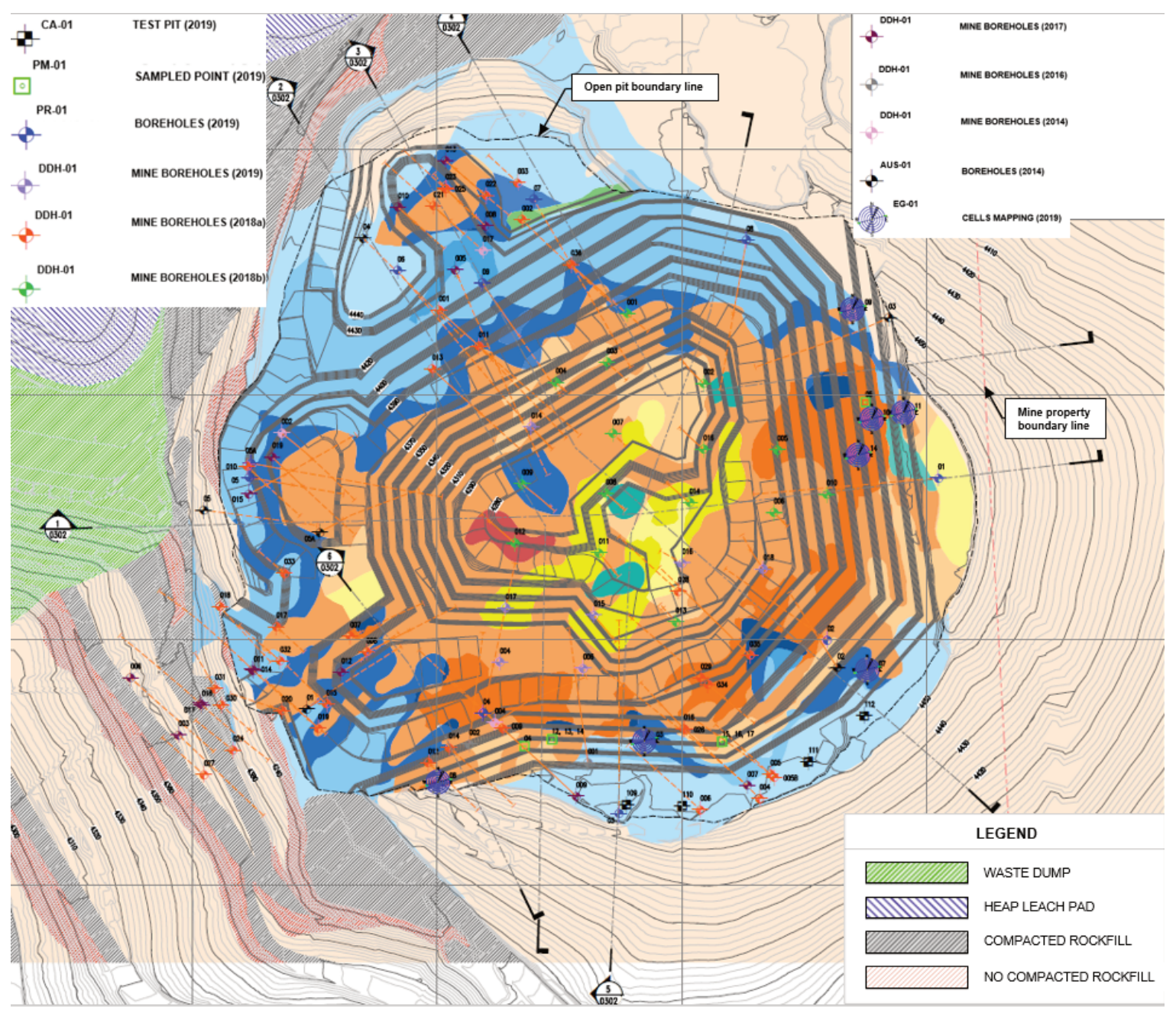

Figure 12 Rock mass quality and alteration of current open pit design (mine design). Table 1 presents values and alteration related to each colour

\section{$4 \quad$ Material properties and slope stability assessment}

Geotechnical characterisation of materials was carried out using Hoek et al. (2002) strength criterion for rock mass with $\mathrm{RMR}_{89} \geq 30$ and Mohr-Coulomb strength criterion for $\mathrm{RMR}_{89}<30$.

Table 4 presents the summary of the rock mass $\left(\mathrm{RMR}_{89} \geq 30\right)$ parameters obtained from the geomechanical model and laboratory testing program. 
Table 4 Rock mass parameters - generalised Hoek-Brown criterion

\begin{tabular}{|c|c|c|c|c|c|c|c|c|}
\hline $\begin{array}{l}\text { Hydrothermal } \\
\text { alteration }\end{array}$ & $\begin{array}{c}\text { Unit } \\
\text { weight } \\
\left(\mathrm{kN} / \mathrm{m}^{3}\right)\end{array}$ & $\begin{array}{l}\mathrm{RMR}_{89} \\
\text { range }\end{array}$ & $\begin{array}{c}\text { GSI } \\
\text { mean }\end{array}$ & $\begin{array}{l}\text { UCS } \\
\text { (MPa) }\end{array}$ & mi & D & $\begin{array}{c}\text { Rock mass } \\
\text { elasticity } \\
\text { moduli (GPa) }\end{array}$ & $\begin{array}{l}\text { Poisson's } \\
\text { ratio }\end{array}$ \\
\hline \multirow{3}{*}{$\begin{array}{l}\text { Advanced } \\
\text { argillic }\end{array}$} & 20.5 & $(30-40)$ & $30 \pm 5$ & 15 & 8 & $0.5 / 0.0$ & $0.750 / 1.400$ & 0.33 \\
\hline & 21.5 & $(40-50)$ & $40 \pm 5$ & 25 & 9 & $0.85 / 0.0$ & $1.436 / 4.790$ & 0.31 \\
\hline & 21.5 & $(50-60)$ & $50 \pm 5$ & 35 & 10 & $0.85 / 0.0$ & $2.535 / 9.215$ & 0.31 \\
\hline \multirow{3}{*}{$\begin{array}{l}\text { Intermediate } \\
\text { argillic }\end{array}$} & 21 & $(30-40)$ & $30 \pm 5$ & 15 & 9 & $0.5 / 0.0$ & $1.000 / 1.600$ & 0.32 \\
\hline & 22 & $(40-50)$ & $40 \pm 5$ & 25 & 9.5 & $0.85 / 0.0$ & $1.675 / 5.587$ & 0.30 \\
\hline & 22 & $(50-60)$ & $50 \pm 5$ & 50 & 11.5 & $0.85 / 0.0$ & $2.959 / 10.752$ & 0.30 \\
\hline \multirow{3}{*}{ Vuggy silica } & 20 & $(30-40)$ & $30 \pm 5$ & 18 & 6 & $0.5 / 0.0$ & $0.450 / 0.900$ & 0.34 \\
\hline & 21 & $(40-50)$ & $40 \pm 5$ & 35 & 8 & $0.85 / 0.0$ & $0.670 / 2.235$ & 0.32 \\
\hline & 21 & $(50-60)$ & $50 \pm 5$ & 75 & 10 & $0.85 / 0.0$ & $1.183 / 4.301$ & 0.32 \\
\hline
\end{tabular}

RMR $_{89}$ - Rock Mass Rating; GSI - Geological Strength Index; UCS - unconfined compressive strength.

Table 5 presents the summary of the rock mass (for $\mathrm{RMR}_{89} \leq 30$ ) and soil parameters obtained from the geomechanical model and laboratory testing developed.

Table 5 Rock mass parameters - Mohr-Coulomb criterion

\begin{tabular}{|c|c|c|c|c|c|c|}
\hline $\begin{array}{l}\text { Hydrothermal } \\
\text { alteration }\end{array}$ & Quality & $\begin{array}{c}\text { Unit } \\
\text { weight } \\
\left(\mathrm{kN} / \mathrm{m}^{3}\right)\end{array}$ & $\begin{array}{c}\text { Cohesion } \\
(\mathrm{kPa})\end{array}$ & $\begin{array}{l}\text { Friction } \\
\text { angle }\left({ }^{\circ}\right)\end{array}$ & $\begin{array}{c}\text { Elasticity } \\
\text { moduli } \\
(\mathrm{MPa})\end{array}$ & $\begin{array}{l}\text { Poisson's } \\
\text { ratio }\end{array}$ \\
\hline Moraine & Soil deposit & 18.0 & 5 & 35 & 70 & 0.36 \\
\hline \multirow{3}{*}{$\begin{array}{l}\text { Advanced } \\
\text { argillic }\end{array}$} & Residual soil & 19 & 120 & \multirow{3}{*}{32} & 150 & 0.35 \\
\hline & $\mathrm{RMR} \leq 20$ & 19.5 & 130 & & 300 & 0.33 \\
\hline & $20<\mathrm{RMR} \leq 30$ & 20.5 & 130 & & 450 & 0.33 \\
\hline \multirow{3}{*}{$\begin{array}{l}\text { Intermediate } \\
\text { argillic }\end{array}$} & Residual soil & 19.5 & 90 & \multirow{3}{*}{30} & 250 & 0.34 \\
\hline & $\mathrm{RMR} \leq 20$ & 20 & 100 & & 400 & 0.32 \\
\hline & $20<\mathrm{RMR} \leq 30$ & 21 & 100 & & 600 & 0.32 \\
\hline \multirow{3}{*}{ Vuggy silica } & Residual soil & 18.5 & 50 & \multirow{3}{*}{30} & 150 & 0.36 \\
\hline & $\mathrm{RMR} \leq 20$ & 19 & 60 & & 220 & 0.34 \\
\hline & $20<\mathrm{RMR} \leq 30$ & 20 & 80 & & 320 & 0.34 \\
\hline \multirow{3}{*}{ Granular silica } & Residual soil & 18.5 & 50 & \multirow{3}{*}{30} & 150 & 0.36 \\
\hline & $\mathrm{RMR} \leq 20$ & 19 & 60 & & 220 & 0.34 \\
\hline & $20<\mathrm{RMR} \leq 30$ & 20 & 80 & & 320 & 0.34 \\
\hline \multirow{3}{*}{ Massive silica } & Residual soil & 18.5 & 50 & \multirow{3}{*}{30} & 150 & 0.36 \\
\hline & $\mathrm{RMR} \leq 20$ & 19 & 60 & & 220 & 0.34 \\
\hline & $20<\mathrm{RMR} \leq 30$ & 20 & 80 & & 320 & 0.34 \\
\hline
\end{tabular}


The slope stability assessment was developed applying the limit equilibrium method using Slide V8.029 (Rocscience 2018) and finite elements method using RS2 V10.010 (Rocscience 2019). Some analysis consideration taken into account are described below:

- Stability analyses were considered through six cross-sections (bi-dimensional analysis). Those section alignments are shown in Figure 12. Factors of Safety (FoS), probability of failure (PoF) and displacements were calculated for all cross-sections, however, cross-section 1 will be the highest wall, that's why is shown in this paper.

- Phreatic level was not considered in the model because it is estimated to be 50 metres below the deepest zone of the pit (based on hydrogeologic study available and nil readings of three vibrating wire piezometers in the final pit footprint).

- Pseudo-static analysis was developed, for closure conditions, in each of the six cross-sections of the open pit. A seismic coefficient of 0.2 (based on United States Army Corps of Engineers (USACE, 2003) recommendations) was used based on the seismic hazard study (updated in 2019), which indicates a Peak Ground Acceleration (PGA) of $0.4 \mathrm{~g}$ in rock (B site type) for a return period of 475 years, which corresponds to a exposure time of 50 years with a probability of exceedance of $10 \%$.

- Current open pit dimensions: Bench height $=15 \mathrm{~m}$, bench width $=8 \mathrm{~m}$, bench face angle $=65^{\circ}$, Interramp-angle $=45^{\circ}$, Maximum inter-ramp/multibench height $=130 \mathrm{~m}$, Maximum overall height $=$ $190 \mathrm{~m}$.

- In this open pit, slope stability is governed by rock mass strength due to be highly fractured.

- Acceptance criteria for different slope scales is based on Read \& Stacey (2009) recommendation:

○ Bench: FoS $(\min )_{\text {static }}=1.1 \&$ PoF $(\max )=25 \%$

○ Multibench/Inter-ramp slope: FoS $(\min )_{\text {static }}=1.3 ; \operatorname{FoS}(\min )_{\text {pseudostatic }}=1.0$ \& PoF $(\max )=10 \%$

- Overall slope: FoS $(\mathrm{min})_{\text {static }}=1.35 ; \mathrm{FoS}(\mathrm{min})_{\text {pseudostatic }}=1.0 \& \mathrm{PoF}_{\max }=5 \%$

Figure 13 shows the results of the slope stability assessment in a sector near to mine property boundary line (view cross-section line 1 in Figure 12). Figure 13 represents the inter-ramp and overall stability conditions for pseudo-static limit equilibrium analyses, which satisfy the acceptance criteria of safety factor. Some modifications to the wall geometry had to be made for this. Trucks loads also were included in geotechnical model $\left(140 \mathrm{kN} / \mathrm{m}^{2}\right.$ for empty truck and $330 \mathrm{kN} / \mathrm{m}^{2}$ for full loaded truck, based on truck technical specifications).

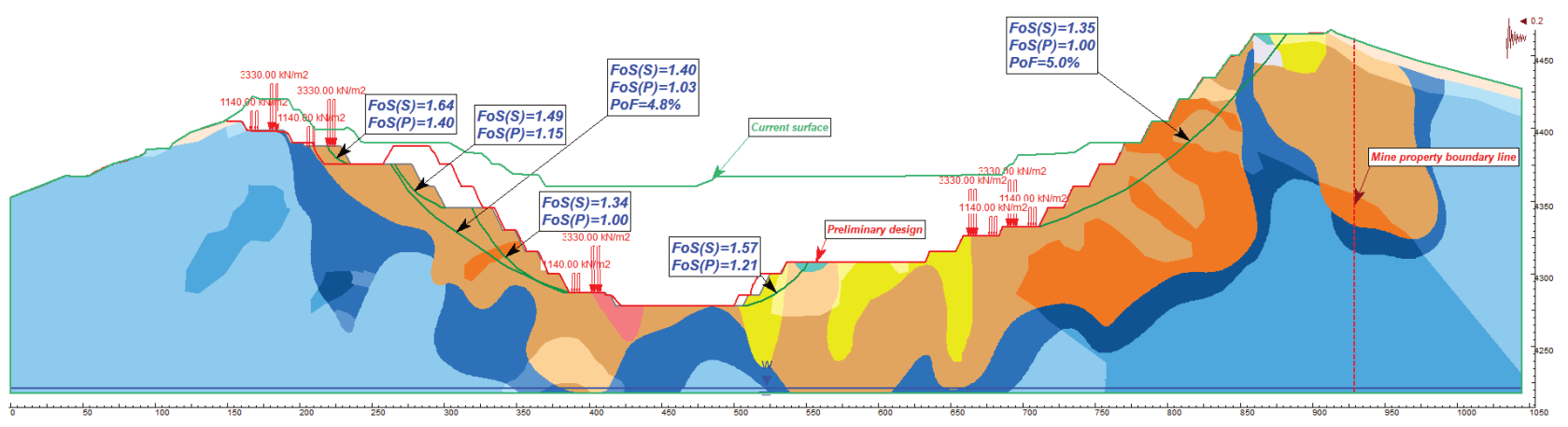

Figure 13 Factors of safety obtained in the slope stability assessment (by limit equilibrium method) in a sector near to mine property boundary line (cross-section 1) 
Figures 14 and 15 shows the results of the stress-strain analysis (used to calculate displacements) and Shear Strength Reduction (SSR) method to compute a critical strength reduction factor (SRF) for the model, obtained in a sector near to mine property boundary line (cross-section 1 ). They show that displacements at the open pit walls are in an acceptable level, therefore these walls are considered stable and it is expected they will operate successfully.

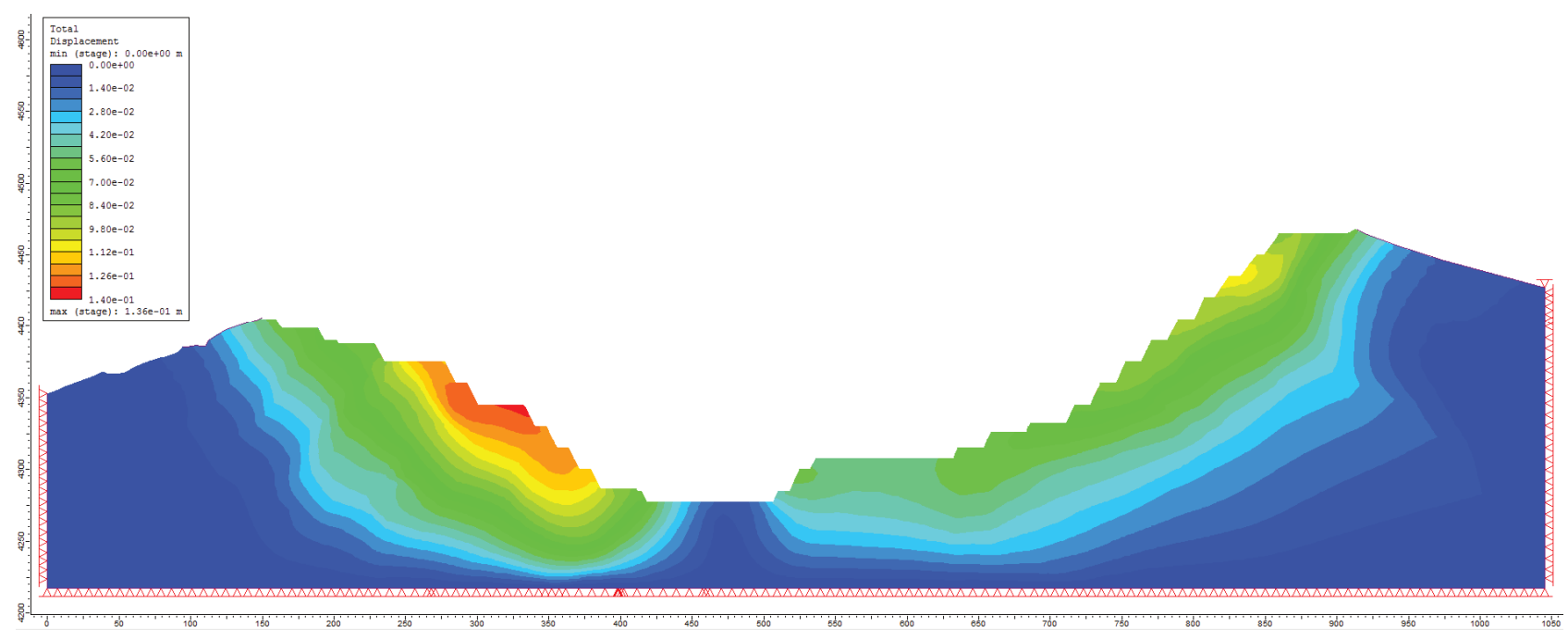

Figure 14 Displacements obtained in a sector near to mine property boundary line (cross-section 1: Maximum displacement $=13.6 \mathrm{~cm}$ )

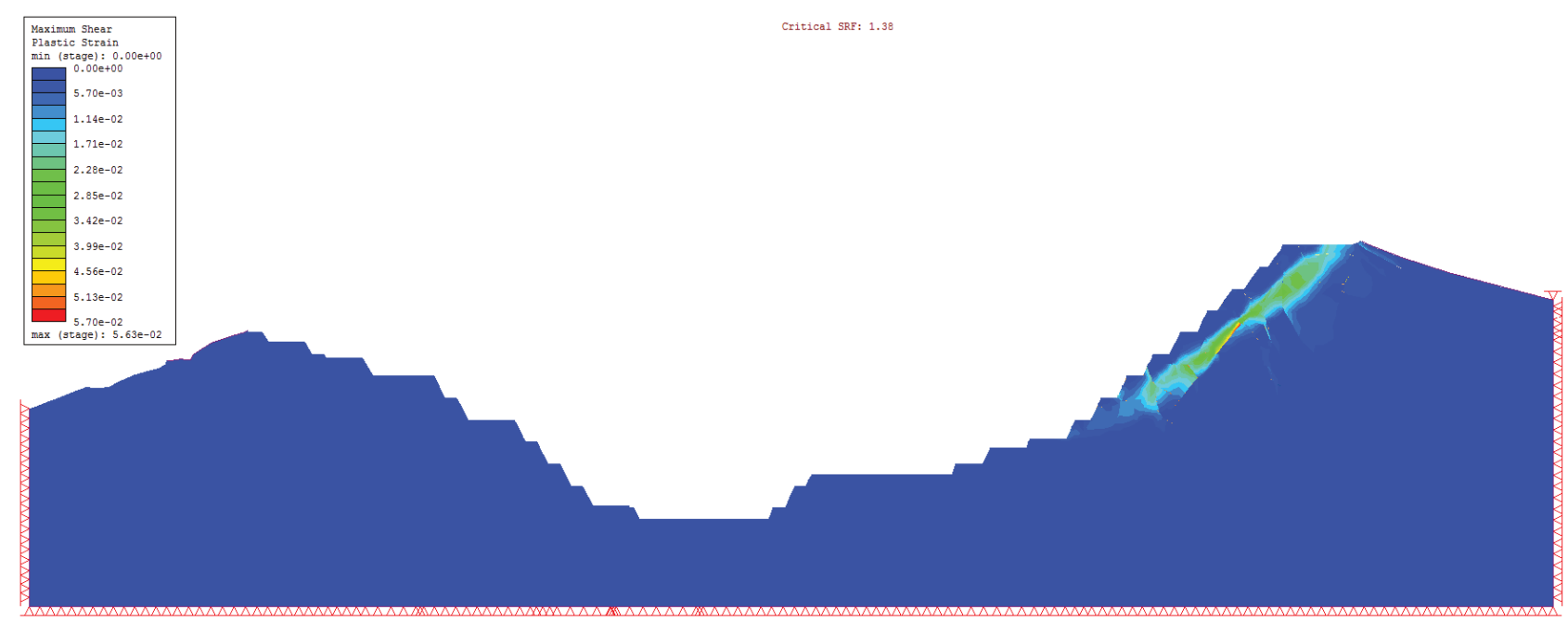

Figure 15 Factor of Safety (obtained by Shear Strength Reduction (SSR) method) in a sector near to mine property boundary line (cross-section 1: strength reduction factor $(\mathrm{SRF})($ static) $=1.38$ ) 


\section{$5 \quad$ Results}

A summary of FoS and displacements of the six cross-sections assessed is presented in Table 6.

Table 6 Ranges of Factor of Safety (FoS) of inter-ramp and overall slopes, and maximum displacements obtained

\begin{tabular}{|c|c|c|c|c|c|}
\hline $\begin{array}{l}\text { Cross- } \\
\text { section } \\
\text { line }\end{array}$ & Slope scale & Static & Pseudostatic & PoF (\%) & $\begin{array}{l}\text { Maximum } \\
\text { displacement } \\
(\mathrm{cm})\end{array}$ \\
\hline \multirow{3}{*}{1} & Inter-ramp (right side) & $1.35-1.57$ & $1.00-1.21$ & $0.0-5.0$ & \multirow{3}{*}{13.6} \\
\hline & Inter-ramp (left side) & $1.35-1.64$ & $1.00-1.40$ & $0.0-5.0$ & \\
\hline & Global (left side) & 1.40 & 1.00 & 4.8 & \\
\hline \multirow{2}{*}{2} & Inter-ramp (right side) & $1.41-1.51$ & $1.00-1.14$ & $0.0-8.0$ & \multirow{2}{*}{15.0} \\
\hline & Inter-ramp (left side) & $1.35-1.63$ & $1.00-1.21$ & $0.0-6.0$ & \\
\hline \multirow{4}{*}{3} & Inter-ramp (right side) & $1.30-1.80$ & $1.00-1.32$ & $0.0-4.5$ & \multirow{4}{*}{16.4} \\
\hline & Global (right side) & 1.45 & 1.04 & 4.0 & \\
\hline & Inter-ramp (left side) & $1.33-1.62$ & $1.01-1.23$ & $0.0-4.1$ & \\
\hline & Global (left side) & 1.39 & 1.00 & 4.8 & \\
\hline \multirow{4}{*}{4} & Inter-ramp (right side) & $1.30-1.41$ & $1.00-1.02$ & $5.0-8.0$ & \multirow{4}{*}{22.0} \\
\hline & Global (right side) & 1.37 & 1.00 & 4.5 & \\
\hline & Inter-ramp (left side) & $1.34-1.39$ & $1.00-1.06$ & $5.3-6.9$ & \\
\hline & Global (left side) & 1.36 & 1.00 & 4.9 & \\
\hline \multirow{4}{*}{5} & Inter-ramp (right side) & $1.30-1.35$ & $1.00-1.03$ & $5.0-7.2$ & \multirow{4}{*}{15.0} \\
\hline & Global (right side) & 1.36 & 1.01 & 4.85 & \\
\hline & Inter-ramp (left side) & $1.30-1.60$ & $1.00-1.19$ & $0.0-7.1$ & \\
\hline & Global (left side) & 1.35 & 1.00 & 5.0 & \\
\hline \multirow{2}{*}{6} & Inter-ramp (right side) & $1.31-1.94$ & $1.00-1.46$ & $0.0-4.7$ & \multirow{2}{*}{3.06} \\
\hline & Inter-ramp (left side) & 2.00 & 1.50 & 0.0 & \\
\hline
\end{tabular}

PoF = Probability of Failure

\section{Conclusion}

To improve the geomechanical model, shallow data collected (bench mapping and logging and some sampling points) was inserted in the model simulating short boreholes. This was valuable data to match the model to the current conditions observed on the open pit walls.

Due to the poor rock quality of most of the final walls of the open pit and the variable strength of rocks affected by hydrothermal alterations, it is recommendable to update the model constantly (better confidence level) through bench mapping during the mining operation.

It is noted (due to RQD values presented in Figure 11), that just a few zones could have slope stability governed by structures. Most of rock mass in the final open pit walls will have RQD values under $25 \%$. 
FoS (static and pseudostatic) and PoF (\%) obtained from the limit equilibrium analysis, satisfy the acceptance criteria stablished for all cross-sections evaluated.

The results of the SSR analysis on cross-section 1, presents a safety factor (SRF) of 1.38 and the maximum displacement reported in the recommended design slopes was approximately $13.6 \mathrm{~cm}$ (upper left interramp). However, it is recommended to update elastic parameters during mining by calibrating displacements of the geotechnical model with those recorded in the monitoring.

Results obtained from cross-section 1 slope stability evaluation, evidences that would be possible to evaluate an expansion of the open pit close to mine property boundary line. For this will be need another slope stability evaluation and a risk assessment. This condition could increase mine life, and it is due to vuggy alteration is the main mineralised rock of the open pit and it is massively presented in East zone (cross-section 1).

The calculated displacements of the deformation analysis and those recorded from the monitoring of topographic prisms being carried out with GeoMos stations, will serve to define alert levels for the operation.

A summary of the recommended open pit dimensions, around the open pit, were: Bench height $=15 \mathrm{~m}$, bench width $=8 \mathrm{~m}$, bench face angle range $=57^{\circ}-70^{\circ}$, Inter-ramp-angle range $=40^{\circ}-48^{\circ}$. It shows the need of update the open pit mine planning and design.

\section{Acknowledgement}

The authors wish to thank Anddes for granting permission to use case study information presented in this paper. The authors also would like to thank Anddes geomechanical team for their continued support.

\section{References}

Bieniawski, Z 1989, Engineering Rock Mass Classification, John Wiley \& Sons, New Jersey.

Deere, DU \& Patton, F 1971, 'Slope stability in residual soils', Proceedings of the Panamerican Conference on Soil Mechanics and Engineering Foundation, Puerto Rico.

Deere, DU, Hendron, AJ, Patton, F \& Cording, EJ 1967, 'Design of surface and near surface excavations in rock', in C Fairhurst (ed.), Proceedings of the 8th US Symposium on Rock Mechanics: Failure and Breakage of Rock, American Institute of Mining, Metallurgical, and Petroleum Engineers, New York, pp. 237-302.

Hexagon Mining 2018, MinePlan ${ }^{T M}$ 3D, version 15.6, computer software, Hexagon Mining, Tucson.

Hoek, E, Carranza-Torres, CT \& Corkum, B 2002, 'Hoek-Brown Failure Criterion - 2002 Edition', Proceedings of the North American Rock Mechanics Society Meeting, Toronto.

Hoek, E, Carter, TG \& Diederichs, MS 2013, 'Quantification of the Geological Strength Index chart', Proceedings of the 47th US Rock Mechanics/Geomechanics Symposium, American Society for Rock Mechanics, Alexandria.

Hoek, E, Kaiser, PK \& Bawden, WF 1995, Support of Underground Excavations in Hard Rock, Rotterdam, A.A. Balkema.

Marinos, P \& Hoek, E 2000, 'GSI: A geologically friendly tool for rockmass strength estimation', Proceedings of the International Conference on Geotechnical and Geological Engineering, GeoEng2000, International Society for Rock Mechanics, pp. 1422-1446.

Martin, D \& Stacey, P 2013, 'Pit slopes in weathered and weak rocks', Proceedings of the 2013 International Symposium on Slope Stability in Open Pit Mining and Civil Engineering, Australian Centre for Geomechanics, Perth, pp. 3-28.

Read, J \& Stacey, P 2009, Guidelines for Open Pit Slope Design, CRC Press/A.A. Balkema.

Rocscience 2018, Slide version 2018, computer software, Rocscience Inc., Toronto.

Rocscience 2019, RS2, computer software, Rocscience Inc., Toronto.

United States Army Corps of Engineers 2003, Slope Stability, Engineering Manual, EM 1110-2-1902. 
Influence of the hydrothermal alteration rocks on the stability of an open pit mine of the south of Peru: a case study 